\title{
QUO VADIS PEMIKIRAN POLITIK ISLAM REFORMULASI STUDI PEMIKIRAN POLITIK ISLAM
}

\author{
MUHAMMAD RIZKY HK \\ UIN MATARAM \\ rizkyhamzar@uinmataram.ac.id
}

\section{Abstract}

This article will discuss the possibility to reformulate the Islamic political thought studies. As a part of both; Islamic Studies, and Political Studies, Islamic Political Thought has been dramatically improved with dialectical moves. The dialectical interaction between Islam as a doctrinal side, with politics which has been known as a more 'humanist' side has created some perplexed among the scholar. This article explains the ambiguity of the relation between Islam and Political Studies and offer a new formula to re-build the Islamic Political Thought Studies. The Authors tried to reformulate the Islamic Political Thought Studies with Reciprocal Integration, by using lan Barbour's theory about the relation between science and religion, Thomas Kuhn's Theory about Normal Science, Keith Ward's theory about The Development of Religion, and Amin Abdullah's theory about integration-interconnection. This article use qualitative research method with descriptive analysis approach through the collection of related literature studies especially. 


\section{A. Pendahuluan}

Kata 'Islam' yang tersemat pada studi pemikiran pemikiran politik islam, memiliki efek ganda. Di satu sisi, kajian keislaman dapat memberi warna dan rupa baru pada bangunan studi pemikiran politik secara umum. Di sisi yang lain, sifat dogmatis yang cenderung kaku dan out-to-date menciptakan sekat-sekat yang kemudian mempersempit cakupan studi pemikiran politik. Dua sisi ini menimbukan problematika yang cukup rumit, baik dari segi teoritis maupun empiris. Istilah Fiqh Siyasah misalnya, atau Siyasah syar'iyyah ${ }^{\prime}$, disajikan dalam bentuk romantisme masa lalu dan hanya sekedar deskripsi sistem tata kelola negara yang mulai dianggap utopis dan kadaluarsa. Atau misalnya dalam bentuk dominasi kajian empiris dari Studi Ilmu Politik, yang cenderung menjadikan

1 Fiqh Siyasah dalam prakteknya lebih condong digolongkan ke dalam pembahasan hukum, sebagaimana pembagian ruang lingkup kajian yang diajukan oleh pemikir politik islam klasik seperti Al-Mawardi, Ibnu Khaldun, Al Farabi hingga Ibnu Taimiyyah, Dasar fiqh siyasah adalah keyakinan bahwa syariat islam bertujuan untuk mewujudkan kemaslahatan umat manusia di dunia dan akhirat dengan menegakkan hukum yang seadil-adilnya meskipun cara yang ditempuhnya tidak terdapat dalam Quran dan Sunnah secara eksplisit. Lihat: A.Djazuli, Fiqh Siyasah, edisi revisi, (Jakarta: Kencana Prenada Media Group, 2003), Al-Mawardi, Al-Ahkam al-Sulthâniyyah, (Beirut: Dâr al-Fikr, 1960), Abu Nashr al-Farabi, Kitab Ârâ' Ahl al-Madînah al-Fadhîlah, ed. by Albir alHusniyyah, (Beirut: Dâr al-Masyriq, 1985), Ibnu Taimiyah, As Siyâsah as Syar'iyah fi islâhir râ'i war ra'iyah, (Riyadh: Maktabah al Muayyad) 
kajian keislaman hanya sebagai pelengkap dan pemanis belaka, tanpa ada pengaruh atau implikasi secara langsung, dari buah fikir para pemikir politik muslim.

Hal ini tentu dikhawatirkan dapat membelokkan arah integrasi keilmuan yang ingin dibangun. Dari semangat integrasi, beralih kepada alienasi terhadap kajian keilmuan tertentu, yang tak pelak akan menjadikan studi pemikiran politik islam menjadi terbatas pada kajian sejarah pemikiran dan teologi, atau sebaliknya, mengalienasi dan mengeliminir kajian keislaman dari bangunan studi pemikiran politik islam. Kondisi ini juga berdampak terhadap mahasiswa peserta didik, Mahasiswa dikhawatirkan akan tersesat dan kehilangan arah di dalam menerjemahkan proses integrasi dua bidang keilmuan yang berbeda, sehingga ada mata rantai yang terputus dalam proses pengajaran, pembelajaran, dan pemahaman dia tentang studi pemikiran politik islam.

Keterputusan mata rantai ini berimplikasi pada kerancuan berfikir yang sebagian besar tergambar dari kegagalan mahasiswa untuk menyerap konsepsi teoritis dan implementasinya pada persoalan-persoalan penelitian akhir mereka. Mahasiswa kesulitan mendeskripsikan ruang lingkup keilmuannya, serta bagaimana menentukan posisinya di tengah 
perkembangan ilmu-ilmu modern dan ilmu-ilmu keislaman, dan seterusnya. Untuk mecegah hal tersebut, dibutuhkan konsepsi yang memadai untuk dapat menjadi dasar penyusunan tahapan sistem pembelajaran studi pemikiran politik islam.

Tulisan ini disusun untuk menyambungkan kembali mata rantai yang hilang dalam diskursus studi pemikiran politik Islam, dan bagi sumbangan pemikiran terhadap pengembangan program studi pemikiran islam, khususnya di Fakultas Ushuluddin dan Studi Agama UIN Mataram. Untuk kepentingan itu, penulis berusaha menerjemahkan beberapa model integrasi keilmuan; Ian Barbour, Amin Abdullah, dan model horizon ilmu UIN Mataram ${ }^{2}$, sebagai alat bantu di dalam me-reformulasi-kan kajian studi pemikiran politik islam. Pada bagian akhir tulisan ini penulis mengajukan Reciprocal Integration sebagai alternatif dan alat bantu di dalam menopang sistem pembelajaran yang berbasis Integrasi keilmuan.

\section{B. Model Integrasi Keilmuan}

2 Horizon ilmu (afaqul ilmi) merupakan rancang bangun keilmuan yang bersumber Quran dan Hadis. Dua sumber utama umat Islam ini ditempatkan sebagai pusat dari keseluruhan disiplin keilmuan yang digeluti. Proses pengembangan ilmu dilakukan dengan memadukan berbagai pendekatan keilmuan untuk dapat menghasilkan insan cendekia. Oleh karena itu, epistemologi yang dikembangkan memadukan antara epistemologi bayani, burhani, dan 'irfani. Lihat: Prof. Dr. Mutawalli, M.Ag., dkk, Horizon IImu: Dasar-Dasar Teologis, Filosofis, dan Model Implementasinya dalam Kurikulum dan Tradisi IImiah UIN Mataram, (Lombok: Pustaka Lombok, 2018). 
Dalam konteks integrasi keilmuan, kita dapat menemukan beberapa konsepsi. Ian Barbour dalam Religion in Age of Science misalnya, mengemukakan 4 model; Conflict, Independence, Dialogue, Integrative ${ }^{3}$. Conflict menempatkan sains dan agama berhadapan sebagai lawan. Sains berpegang pada logika dan data, sedang agama berpegang pada ayat suci. Independence, menggambarkan masing-masing studi sebagai dua objek kajian yang berbeda, yang mandiri dan memiliki otonomi tersendiri. Dalam model Dialogue sains dan agama berdialog secara tidak langsung untuk mencari titik temu diantara keduanya. Relasi mulai terjalin lewat batasan pertanyaan, dan metodologi yang saling berhubungan. Sementara Integrative memandang sains dan agama dapat saling berkontribusi di dalam pengembangan kajian keilmuan keduanya.

Keterlibatan Agama yang dianggap 'tidak ilmiah' dalam proses pengembangan sains pun didukung oleh Teori yang diajukan Tomas Kuhn. Dalam The Structure of Scientific Revolutions, Kuhn mengatakan bahwa seluruh metode yang selama ini diklaim meliputi observasi, eksperimen, penalaran deduksi dan induksi telah menjadi semacam ilusi. Karena pada $5-25$.

${ }^{3}$ Ian Barbour, Religion In An Age Of Science, ( San Fransisco: Harper, 1990), hal. 
akhirnya, paradigma lah yang menjadi dasar penentuan jenis, arah, pertanyaan dari suatu eksperimen ilmiah. Kebenaran sebuah teori bisa diuji melalui verifikasi maupun falsifikasi, yang utama adalah kebenaran tersebut tidak didasarkan kepada kriteria objektif, tetapi juga pada kriteria 'subjektif' dari sebuah komunitas ilmiah. Akhirnya 'konsensus'-lah yang menjadi dasar epistemologis yang paling relevan dalam pemahaman kita mengenai ilmu tertentu ${ }^{4}$. Dengan kata lain, kajian keislaman pun dapat dikategorikan sebagai paradigma keilmuan, yang tidak hanya disandarkan pada khalayan metafisik atau perenungan batiniyah, melainkan tersusun atas metode, dan objek keilmuan yang jelas, dan secara konsensus diterima sebagai bagian dari khazanah keislaman.

Amin Abdullah, dalam Islamic Studies di Perguruan Tinggi Pendekatan Integratif-Interkonektif, menawarkan konsep integrasi-interkoneksi untuk menolak dikotomi keilmuan umum dengan keilmuan islam. Amin mengajukan paradigma pemikiran yang modest (mampu mengukur kemampuan diri sendiri), humble (rendah hati) dan humanity (manusiawi). Kompleksitas persoalan kehidupan manusia, dan setiap kajian keilmuan

${ }^{4}$ Thomas S. Kuhn, The Structure of Scientific Revolutions, 2d,ed. (Chicago: University of Chicago Press, 1970).

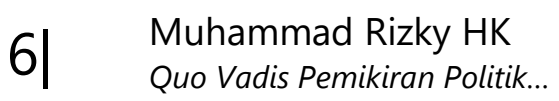

POLITEA : Jurnal Politik Islam Vol. 4 No.1 Januari-Juni 2021 
dipandang sebagai sesuatu yang tidak dapat berdiri sendiri ${ }^{5}$. Kajian keislaman tidak dipahami sebagai kajian yang hanya berbicara mengenai persoalan ketuhanan, kepercayaan,dogma, pandangan hidup, dan tujuan ultim, melainkan berkaitan langsung, meskipun tidak secara keseluruhan, dengan persoalan-persoalan historis-kultural.

Menurut Amin, bangunan keilmuan yang lazim dipraktekkan di PTAI adalah model single entity di mana pengetahuan agama berdiri sendiri tanpa memerlukan bantuan metodologi yang digunakan oleh ilmu pengetahuan umum; atau isolated entities di mana masing-masing rumpun ilmu berdiri sendiri, tanpa saling bersentuhan dan bertegur sapa secara metodologis, dan belum mau menerima atau belum mampu menerapkan model interconnected entities. Bagi Amin, idealnya kita semua beranjak kepada interconnected entities ${ }^{6}$, di mana setiap disiplin ilmu memiliki kesadaran akan keterbatasannya dalam memecahkan persoalan manusia, lalu menjalin hubungan kerjasama dalam proses pendekatan dan prosedur penalaran serta penelitian.

${ }^{5}$ Amin Abdullah, Islamic Studies di Perguruan Tinggi: Pendekatan IntegratifInterkonektif, (Yogyakarta: Pustaka Pelajar, 2006), h. viii

${ }^{6}$ Amin Abdullah, Islam dan Modernisasi Pendidikan di Asia Tenggara: Dari Pola Pendekatan Dikotomis-atomistik kearah integratif-interdisiplinary , Makalah disampaikan dalam Konferensi Internasional Antar Bangsa Asia Tenggara, Universitas Gadjah Mada, Yogyakarta, 10 - 11 Desember 2004. 
Konsep integrasi ala Amin tertuang dalam struktur keilmuan yang digagas yaitu; 'Ulûm ad-Dîn (Religious Knowledge), al-Fikr al-Islâmiy (Islamic Thought) dan Dirasat Islâmiyyah (Islamic Studies). 'Ulûm ad-Dîn mengacu kepada "tradisi lokal" keislaman, dengan "bahasa" dan "teks-teks" atau nash-nash keagamaan sebagai landasan; al-Fikr al-Islamiy menggambarkan hasil dialektika pemikiran keislaman yang bertolak dari "rasio-intelektual”, sedangkan Dirasat Islamiyyah adalah bidang keilmuan baru yang berdiri di atas paradigma keilmuan sosial kritis-komparatif yang melibatkan seluruh "pengalaman" (experiences) umat manusia. ${ }^{7}$

Konsepsi ini sesuai dengan model perkembangan agama yang ditawarkan Keith Ward. Menurutnya agama berkembang dalam 4 fase; Lokal, Kanonikal, Kritikal, dan Global ${ }^{8}$. Pada tahap lokal, agama berkembang dalam lingkup sempit dan masih dalam bentuk ritual atau mitos yang diwariskan melalui tradisi bahasa lisan. Tahap kanonikal ditandai dengan mulai berkembangnya proses rasionalisasi dan moralisasi terhadap teks maupun tradisi keagamaan yang muncul pada tahap lokal.

${ }^{7}$ Amin Abdullah, "Mempertautkan 'Ulûm ad-Dîn, al-Fikr Al-Islamiy dan Dirasat Islam-iyyah: Sumbangan Keilmuan Islam Untuk Peradaban Global”, http://aminabd.wordpress.com/2010/06/20/mempertautkan-ulum-al-diin-al-fikr-alislamiy-dan-dirasat-islamiyyah-sumbangan-keilmuanislam-untuk-peradaban-global/, diakses 17 September 2020

${ }^{8}$ Keith Ward, The Case of Religion (Oxford: Oneworld, 2004), hal 220-228. 
Pada tahap kritikal, mulai muncul respon atas norma dan aturan mengikat, yang muncul pada tahap kanonikal. Respon kritis mulai muncul atas aturan-aturan, sekaligus menggugat klaim kebenaran absolut dan universalitas yang muncul pada tahap kanonikal. Tahapan keempat; Tahapan Global, Muncul kesadaran bahwa agama merupakan bagian dari keunikan religiusitas manusia, yang kemudian membuka ruang dialog dengan mencari titik temu antar pemeluk agama.

Dari pemaparan berbagai konsep di atas, tentu lebih mudah bagi kita untuk menentukan kemana arah integrasi keilmuan yang akan diinfiltrasikan ke dalam tubuh studi pemikiran politik islam. Dari konsepsi Barbour, relasi yang terbangun antara studi keislaman dengan studi ilmu politik masih berada pada keadaan 'independence'; suatu keadaan di mana masing-masing studi dilihat sebagai dua objek kajian yang berbeda, yang mandiri dan memiliki otonomi tersendiri. Maka keseimbangan antara keduanya menjadi tantangan sendiri, yang belum tentu bisa menyelesaikan persoalan. Pemberian porsi yang besar bagi kajian keislaman, dikhawatirkan akan menimbulkan ortodoksi dan kejumudan berfikir, sementara di sisi lain, Alienasi yang berlebihan terhadap kajian keislaman akan menimbulkan sifat alergi dan curiga terhadap segala sesuatu yang 'berbau' Islam, dan 
menimbulkan 'kemiskinan intelektual' di kalangan mahasiswa islam.

\section{Reciprocal Integration}

Dalam proses peralihan menuju model integratif, maka dibutuhkan penjabaran yang jelas mengenai Orbit Point, maupun komposisi keilmuan yang mengitarinya. Keduanya akan memberikan gambaran tentang bidang keilmuan, pendekatan, maupun lokus serta fokus keilmuan yang dibangun.

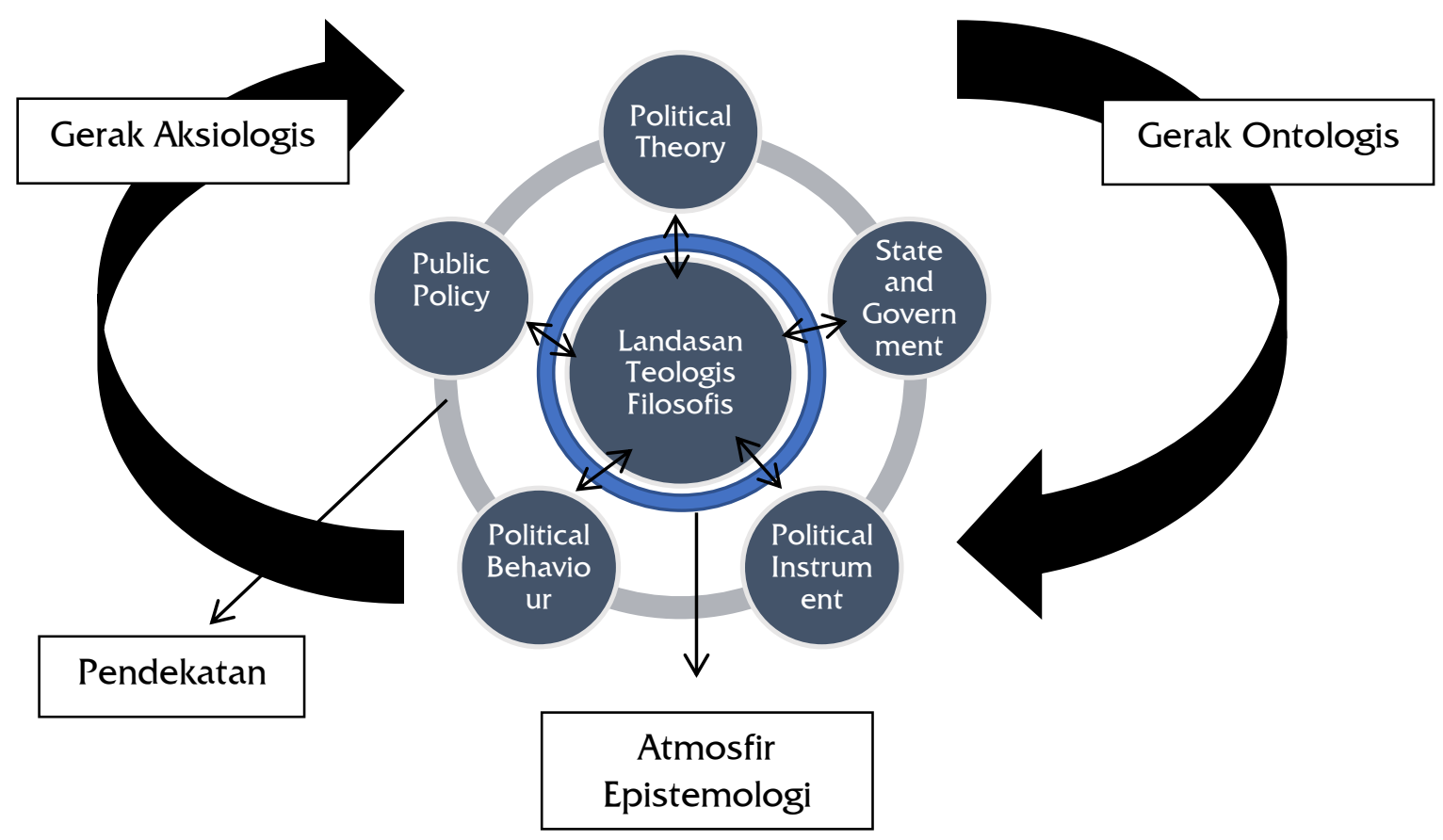

Dalam konteks Studi Pemikiran Politik Islam, Islamic Studies berperan menjadi menjadi titik orbit, yang menjadi 
pusat dari perputaran diskursus keilmuan pemikiran politik islam. Tentunya dalam wujud kerangka teologis filosofis, yang menggambarkan respon para pemikir muslim yang dihadapkan pada tantangan untuk turut terlibat aktif secara keilmuan dalam perbincangan dan pembahasan yang mendalam tentang isu-isu kemanusiaan kontemporer ${ }^{9}$, seperti hak asasi manusia, gender, pluralitas agama, hubungan internasional, radikalisme,dan lain sebagainya. Teologi tidak lagi dibatasi pada bentuk relasi manusia dengan Tuhan saja, melainkan dalam bentuk relasi antar-manusia dengan berdasar kepada pemahaman teologis tentang sifat-sifat kebaikan yang diatributkan kepada Tuhan. Filosofi tidak lagi berbicara pada tataran konsepsi ide metafisis belaka, melainkan berbicara tentang relasi antar manusia, baik sebagai subjek maupun objek.

Landasan teologis-filosofis dalam prakteknya, diimplementasikan dalam bentuk mata kuliah; 'Ulumul Qur'an, 'Ulumul Hadis, Ushul Fiqh, Islam sains dan Peradaban, serta Tauhid dan Ilmu Kalam. Keseluruhannya ditopang dengan penguasaan bahasa teks Quran dan Hadis melalui mata kuliah bahasa arab, Landasan filosofis terejawantahkan lewat mata

${ }^{9}$ Amin Abdullah, "Mempertautkan 'Ulûm ad-Dîn, al-Fikr Al-Islamiy dan Dirasat Islam-iyyah: Sumbangan Keilmuan Islam Untuk Peradaban Global” 
kuliah Filsafat Ilmu, dan Filsafat Islam, yang diikat dengan mata kuliah filsafat. Keduanya menjadi orbit dari proses transformasi keilmuan dengan metode pembauran paradigma berbagai ilmu dan menghubungkannya satu dengan yang lain, dalam rangka membangun model keilmuan interdisipliner-komprehensif, sehingga terwujud suatu tatanan pengetahuan praksis holistik yang berlaku dan mengamati serta merubah kehidupan masyarakat.

Studi keislaman secara resiprokal, menyerap dan merefleksikan dan secara epistemologis, memperkaya lapisan konsep, pendekatan, teori serta paradigm masing-masing masing-masing diskursus bidang studi, dengan gaya tarik menarik, menjaga perputaran diskursus keilmuan politik islam tetap pada orbitnya. Inilah kemudian yang menimbulkan reciprocal integration diantara; Studi Keislaman di satu sisi, dengan Studi Ilmu Politik di sisi lain. Gerak resiprokal tidak melebihkan atau mengurangi peran datu dari yang lain, melainkan menjadi bentuk integrasi yang terus menerus. Landasan Teologis Filosofis, menjadi matahari; tidak dapat dilihat dengan mata telanjang, tetapi dapat dirasakan keberadaannya. 
Dalam bagan di atas, 5 Kajian Inti dalam Studi Ilmu Politik; Political Science, State and Government, Political Instrument, Political Behaviour, dan Public Policy, dengan gaya tarik menarik, berputar dengan Landasan Teologis-Filosofis sebagai pusat orbit. Lima kajian tersebut merangkum sembilan (9) subdisiplin yang berada dalam naungan ilmu politik, yaitu; Ilmu Politik (Political Science), Lembaga-lembaga politik, Tingkah Laku Politik, Politik Komparatif, Hubungan Internasional, Teori Politik Administrasi dan Kebijakan Publik, Ekonomi Politik dan Metodologi Politik. ${ }^{10}$ Masing-masing bidang kajian ilmu politik terhubung oleh pendekatanpendekatan. Pendekatan yang paling umum digunakan adalah Pendekatan tradisional, Behavioral, dan Post-Behavioural. Sementara David Apter mengajukan 6 pendekatan, di antaranya; Filsafat Politik; Institusionalisme; Behavioralisme; Pluralisme; Strukturalisme; Developmentalisme. ${ }^{11}$ Seluruh gerak dihubungkan oleh pendekatan dan dibatasi oleh keunikan epistemologis tiap bidang kajian. Masing-masing bidang kajian, merefleksikan locus keilmuan politik islam, yang menjadi dasar penelitian bidang studi. Selanjutnya secara ontologis, diskursus keilmuan berputar dengan Political Theory sebagai titik tolak.

${ }^{10}$ Robert E. Goodin and Hans-Dieter Klingemann, A New Handbook of Political Science, (New York: Oxford University Press, 1996), hal.103.

${ }^{11}$ David E. Apter, Pengantar Analisa Politik (Jakarta: Rajawali, 1985), hal. 46 
Ontologi Ilmu politik yang sekurang-kurangnya terdiri dari; Negara, Kekuasaan, Pengambilan Keputusan, Kebijakan Publik serta Distribusi Kekuasaan ${ }^{12}$, dibongkar terlebih dahulu secara ontologis. Dengan berpijak pada sisi teoritis (theoretical side); pemahaman mendalam terhadap teori-teori politik, meneropong lembaga-lembaga pemerintahan, serta instrument politik, dan menggiring kepada pemahaman ontologis tentang tiap-tiap sub-kajian; Teori Politik Klasik hingga kontemporer; Lembaga Pemerintahan, Hubungan Antar-Lembaga Politik dan Instrumen-Instrumen Politik.

Kemudian gerak berlanjut menuju sisi aksiologis, yang kemudian menjadi empirical side. Bertitik tolak pada Political Behaviour, dengan sub-kajian; Etika dan Perilaku Politik, Komunikasi dan Strategi Politik, dan Organisasi Kepemimpinan Politik. Kemudian bergerak secara aksiologis menuju Kajian Public Policy dengan sub-kajian; Proses Legislasi, Politik Anggaran, Proses Decision-making, dan lain sebagainya. Dalam konteks aksiologis-empiris ini, Ilmu Politik dimaknai sebagai Ilmu yang mempelajari hubungan interaksi antara pemerintah dan masyarakat, dalam rangka proses pembuatan dan

${ }^{12}$ Miriam Budiarjo, Dasar-Dasar imu Politik (Jakarta: Gramedia, 1982), hal 9. 
pelaksanaan keputusan yang mengikat berdasarkan kebaikan bersama masyarakat yang menetap di suatu wilayah tertentu. ${ }^{13}$

Sisi ontologis dari integrasi merefleksikan bahwa setiap bidang keilmuan berakar dari asumsi, artikulasi dari nilai ke dalam definisi. Ketika sisi ontologis dari semua ilmu adalah sama, maka setiap ilmu pun akan memiliki dimensi dari sistem pengetahuan (yang membangun keilmuan bersangkutan) yang memiliki keterkaitan dengan keilmuan yang lain, khususnya ketika dimasukkan ke dalam narasi ilmiah. Kajian mengenai public policy tidak bisa terpisah dari sisi teoritis, dan pada dasarnya merefleksikannya, sesuai dengan gerak rotasi. Begitu pula kajian teori politik, tidak dapat terpisah dari kajian political behavior karena merupakan titik tolak pemahaman ontologis dari bangunan kajian pemikiran politik islam. Keterkaitan antarkajian keilmuan dibangun dengan pendekatan yang saling terikat, saling menghubungkan satu sama lain, dengan dilindungi astmosfer epistemologi yang menjaga keunikan masing-masing bidang kajian.

Di sinilah peran integrasi keilmuan, di mana setiap subjek, diintegrasikan dalam suatu tatanan jaringan sistemik, yang tidak hanya berkutat pada ruang lingkup pengetahuan dan

${ }^{13}$ Ramlan Surbakti, Memahami Ilmu Politik, (Jakarta: Gramedia Widia Sarana Indonesia, 1999), hal 1. 
metodologi, namun bekerja menerus hingga ke tahap aksiologis menjangkau fungsi mekanistik membangun realitas masyarakat sebagai refleksi dari organisme plural, terpadu, dan multiperspektif. Integrasi keilmuan membutuhkan pemahaman ontologis-teoritis yang mendalam terhadap bidang ilmu yang akan diintegrasikan. Proses tersebut menuntut pembentukan jenjang pengetahuan, mengurainya dalam struktur analisa yang terpusat. Sehingga inti dari muatan keilmuan itu dapat tersentuh dan dijadikan atmosfir epistemologis dari horizon keilmuan studi pemikiran politik islam.

\section{Dari Integrasi menuju Internalisasi}

Berdasarkan pola tersebut, Staf pengajar dituntut untuk dapat menemukan inti keilmuannya yang bersifat dependen, memahami hubungannya dengan disiplin yang lain, dan dengan pola integratif memperkaya keilmuan dengan perspektif lain. Gerak berputar ini selanjutnya menghasilkan internalisasi, di manasetiap bidang ilmu yang telah diintegrasi-interkoneksikan tentu memiliki muatan multiperspektif.
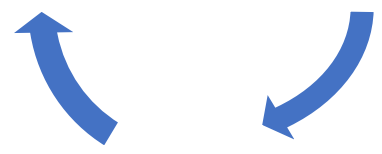

Empiris 
Pada tahap inilah terbentuk horizon ilmu, di mana aspek kognitif, afektif dan psikomotorik dari objek internalisasi pun akan mencerminkan keluasan dan keterbukaan cara pandang. Konstelasi berbagai kajian keilmuan membentuk 'ufuk' sebagai refleksi atas ragam interpretasi dan artikulasi dari keseluruhan perspektif yang ada hingga ia mencapai tapal batas 'penglihatan' akal dan spiritualnya. ${ }^{14}$

Internalisasi dapat dipahami sebagai ujung dari proses integrasi resiprokal ini. Tanpa adanya internalisasi, Integrasi hanya menjadi jargon, dan tidak bersifat resiprokal. Integrasi resiprokal memahami hubungan antar-kajian keilmuan sebagai gaya tarik menarik yang tak pernah putus. Keterputusan mata rantai, selanjutnya, dapat diatasi dengan menjalin hubungan keterkaitan satu sama lain, tidak mengalienasi salah-satu bidang keilmuan, tetapi membangun siklus integratif yang mengaitkan satu sama lain.

\section{E. Penutup}

Studi Pemikiran Politik Islam, mengikuti gerak dialektik, terus menerus mencari bentuk. Dalam prosesnya, dibutuhkan eksperimen-eksperimen yang lebih berani dan komprehensif.

${ }^{14}$ Lihat: Muh. Alwi Parhanudin, Buku Pedoman Implementasi Horizon Keilmuan Program Studi Pemikiran Politik Islam, (Mataram: PPI UIN Mataram, 2019), Hal. 10. 
Pola pencarian distingsi keilmuan, menjadi tugas besar program studi, di dalam usaha merefleksikan dan memperjelas semangat keilmuan yang ingin dibangun.

Berdasarkan Orbit keilmuan di atas, maka gambaran proses pembelajaran disajikan dengan pola integrative, yang berlangsung secara terus menerus. Landasan teoritis-filosofis menjadi orbit perputaran diskursus, dengan wajah Islamic studies yang lebih humanis, Teoritisasi Ilmu Politik (theoretical side) menjadi titik tolak gerak ontologis, dalam memahami Lembaga-lembaga pemerintahan, hubungan antar pemerintahan, dan Instrumen-Instrumen Politik. Kajian atas Perilaku politik (empirical side) menjadi titik tumpu gerak aksiologis, yang meneropong; Etika dan Perilaku Politik, Komunikasi dan Strategi Politik, dan Organisasi Kepemimpinan Politik. Kemudian bergerak secara aksiologis menuju Public Policy dengan sub-kajian; Proses Legislasi, Politik Anggaran, Proses Decision-making, dan lain sebagainya.

Seluruh gerak dihubungkan oleh pendekatan dan dibatasi oleh keunikan epistemologis tiap bidang kajian. Masing-masing bidang kajian, merefleksikan locus keilmuan politik islam, yang menjadi dasar penelitian mahasiswa, Interaksi epistemology dan pendekatan akan melahirkan fokus keilmuan yang dapat 
dikaji dan diteliti, dengan tidak menyampingkan; baik theoretical side maupun empirical side. Dibutuhkan keseimbangan di dalam perputaran diskursus keilmuan. Bukankah keteraturan alam semesta terjadi karena keseimbangan dan kesinambungan gerak seluruh komponen penyusunnya.

\section{DAFTAR PUSTAKA}

Abdullah, Amin, Islam dan Modernisasi Pendidikan di Asia Tenggara: Dari Pola Pendekatan Dikotomis-atomistik kearah integratif-interdisiplinary, Makalah disampaikan dalam Konferensi Internasional Antar Bangsa Asia Tenggara, Universitas Gadjah Mada, Yogyakarta, 10 11 Desember 2004.

"Mempertautkan 'Ulûm ad-Dîn, al-Fikr Al-Islamiy dan

Dirasat Islam-iyyah: Sumbangan Keilmuan Islam Untuk Peradaban

Global", http://aminabd.wordpress.com/2010/06/20/memperta utkan-ulum-al-diin-al-fikr-al-islamiy-dan-dirasatislamiyyah-sumbangan-keilmuanislam-untukperadaban-global/, diakses 17 September 2020 
"Mempertautkan 'Ulûm ad-Dîn, al-Fikr Al-Islamiy dan

Dirasat Islam-iyyah: Sumbangan Keilmuan Islam Untuk Peradaban Global” Islamic Studies di Perguruan Tinggi: Pendekatan Integratif-Interkonektif, (Yogyakarta: Pustaka Pelajar, 2006).

Al-Farabi, Abu Nashr Kitab Ârâ' Ahl al-Madînah al-Fadhîlah, (Beirut: Dâr al-Masyriq, 1985)

Al-Mawardi, Al-Ahkam al-Sulthâniyyah, (Beirut: Dâr al-Fikr, 1960)

Apter, David E, Pengantar Analisa Politik (Jakarta: Rajawali, 1985).

Barbour, Ian, Religion In An Age Of Science, ( San Fransisco: Harper, 1990).

Budiarjo, Miriam, Dasar-Dasar imu Politik (Jakarta: Gramedia, 1982).

Djazuli, A, Fiqh Siyasah, edisi revisi, (Jakarta: Kencana Prenada Media Group, 2003).

Mutawalli, M.Ag., dkk, Horizon Ilmu: Dasar-Dasar Teologis, Filosofis, dan Model Implementasinya dalam Kurikulum dan Tradisi IImiah UIN Mataram, (Lombok: Pustaka Lombok, 2018). 
Parhanudin, Muh. Alwi, Buku Pedoman Implementasi Horizon Keilmuan Program Studi Pemikiran Politik Islam, (Mataram: PPI UIN Mataram, 2019).

Ramlan Surbakti, Memahami Ilmu Politik, (Jakarta: Gramedia Widia Sarana Indonesia, 1999).

Robert E. Goodin and Hans-Dieter Klingemann, A New Handbook of Political Science, (New York: Oxford University Press, 1996).

Taimiyah, Ibnu, As Siyâsah as Syar'iyah fi islâhir râ'i war ra'iyah, (Riyadh: Maktabah al Muayyad)

Thomas S. Kuhn, The Structure of Scientific Revolutions, 2d,ed. (Chicago: University of Chicago Press, 1970).

Ward, Keith, The Case of Religion (Oxford: Oneworld, 2004). 
